\title{
Environmental Technologies for Use of Coal Mining and Chemical Industry Wastes
}

\section{Myroslav Malovanyy ${ }^{1 *}$, Yaroslav Lyashok², Sergiy Podkopayev², Olexiy Povzun², Olexandr Kipko², Valeriy Kalynychenko², Svitlana Virich², Alla Skyrda²}

\author{
1 Institute for Sustainable Development, Lviv Polytechnic National University, 12, Stepan Bandera Str., Lviv, \\ 79013, Ukraine \\ 2 Donetsk National Technical University, 2, Shibankova Square, Pokrovsk, 85300, Ukraine \\ * Corresponding author's e-mail: mmal@lp.edu.ua
}

\begin{abstract}
The purpose of the research was to raise the level of environmental safety in the coal mining regions by using combustion metamorphic rocks of the spoil banks, which were reinforced with the modified wastes of the polymer production, namely carbonous binders, as a man-made raw material for the base courses of roads. The environmentally friendly technology for the construction of the base course of roads from layers of combustion metamorphic rock mixtures (CMRM) with different largest granule size of crushed stone was developed. The bulk density and compressive strength in a cylinder on a hydraulic press were used as the criteria for determining the rational granulometric composition. The practicability of reinforcing combustion metamorphic rocks with coal tar, which is a modified waste of the polystyrene production, i.e polystyrene dust, was shown. The technology of preparation of the tar and polystyrene binder (TPB) was developed. The optimal concentration of polystyrene dust in the organic binder of the coke production and the time of their combination (as the optimal areas of admissible values of variation factors $X_{1}, X_{2}, X_{3}$ ) were determined using the method of mathematical planning of the three-factor experiment ( 5 optimization parameters). The coefficients of the regression equations were calculated using the least squares method. Regression equations are a second-degree polynomial. The three-dimensional diagrams "parameters of system optimization - variance factors" were calculated and drawn. In accordance with the obtained regression equations, the response surface was designed in a three-dimensional space. The areas of admissible values of optimal variance factors correspond to the limit values of the response functions.
\end{abstract}

Keywords: wastes, ecological danger, technogenic raw materials, utilization, modeling, optimization.

\section{INTRODUCTION}

As for the industrial pollution, Ukraine is the leader in Europe. Ukraine has more than 1,700 harmful enterprises. Out of these, the chemical, metallurgical and coal mining enterprises which are found in the residential (Fig. 1) and recreational areas are particularly dangerous. The morbidity and mortality rates of the Ukrainian population are the worst in Europe (Kuzyk and Artamonov 2013).

The waste utilization in Ukraine is significantly lower than its actual capacity. Despite its growth, the waste utilization accounts for
$10-20 \%$ of the total waste (Shago et al., 2011), while in the more economically developed countries of the world, it is 65-80\% (Syvyj 2012). The key problem of the present day concerning the reduction of the use of natural resources by maximum recycling of waste (reuse for practical purposes) has not been solved. In order to do this, it is necessary to take into account the possibility of utilizing material things at the stage of their development and designing the waste utilization plants (Shago et al., 2011).

In Ukraine, $18 \%$ of the total amount of waste corresponds to the coal mining and coal enrichment wastes, $10 \%$ is the metallurgical industry 


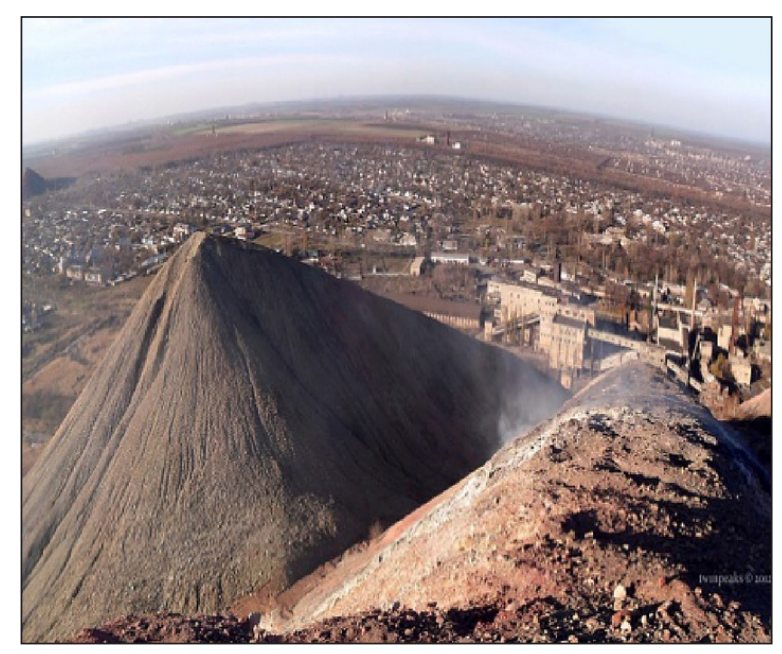

Fig. 1. A soil bank in a residential area

wastes, while $4 \%$ - the ashes and slag wastes from the power stations and boiler houses (Kasymov et al. 2010).

The development of the coal mining industry has been of particular importance to Ukraine. In the $21^{\text {st }}$ century coal becomes the major and soon the main energy source. The largest coal regions of Ukraine include Donetsk, Lviv-Volynskyi bituminous coal basins and Dniprovsky brown coal basin, the total area of which is 3\% of the Ukraine's area. The large-scale application of energy, resource-intensive technologies and exhausting nature management has led to a significant ecological footprint and pollution of the environment. Since the time Ukraine became independent, the ecological footprint has decreased; however, there are still destructive processes in the environment, which pose a threat to the environment itself as well as the population of the country.

All existing methods of underground coal mining are related to the formation of rock dumps on the surface of the earth. Annually, about 40 million $\mathrm{m}^{3}$ of rock is raised to the surface and piled in the dumps due to the process of underground coal mining in Ukraine, As a result of 200 years of coal mining and annual accumulation of industrial waste of 167-214 million tons, there are more than 1,100 soil banks in the country (Polulyax et al. 2012), which occupy 6,300 hectares of fertile land which is suitable for the industry and housing construction. The soil banks are sources of adverse effects on the state of the air, the quality of surface and groundwater and the chemical composition of agricultural land (Pivnyak et al., 2011). Coal mining is related to the destructive effects on the atmosphere, land and water resources, flora and fauna, which can result in the collapse of the rock massif over the stope ore, drainage of aquifers, salinization and contamination of soils, groundwater and surface water, etc. (Gorova et al. 2013).

At present, the issue of increasing the complex use of both products and wastes from the mining industry is of high priority. Despite the close attention to these problems by many scholars, they are still acute. This is primarily due to the fact that the level of environmental pollution of the coal mining regions has recently become critical.

Particularly acute is the problem of utilizing the man-made raw materials in the industrially developed Donets Basin, in the structure of the economic complex where the coal industry is one of the leading industries. This industrial region occupies only $5 \%$ of the country's area, and its share accounts for $40 \%$ of harmful wastes (Bogach 2013).

Most spoil banks of Donets basin are burning (Fig. 2); even if a spoil bank seems to be extinguished, in fact, it continues to smoulder. There is a high temperature in inside; besides, there is a lot of accumulated arsenic, mercury, cyanides, sulfur as well as other harmful substances and their compounds.

On average, about 10 tons of carbon monoxide, 1.5 tons of sulfur dioxide and a significant number of impurities of other gases are released from one burning spoil bank per day (Pavlychenko et al., 2014). As a result of the chemical and thermal reactions, the burning spoil banks emit a large number of various chemical compounds. In this case, toxic volatile components are formed: phenol, formaldehyde, monoethanol, and other components. (Maznyczka et al., 2011). According to Voycehovskaya et al. (2012), the excess

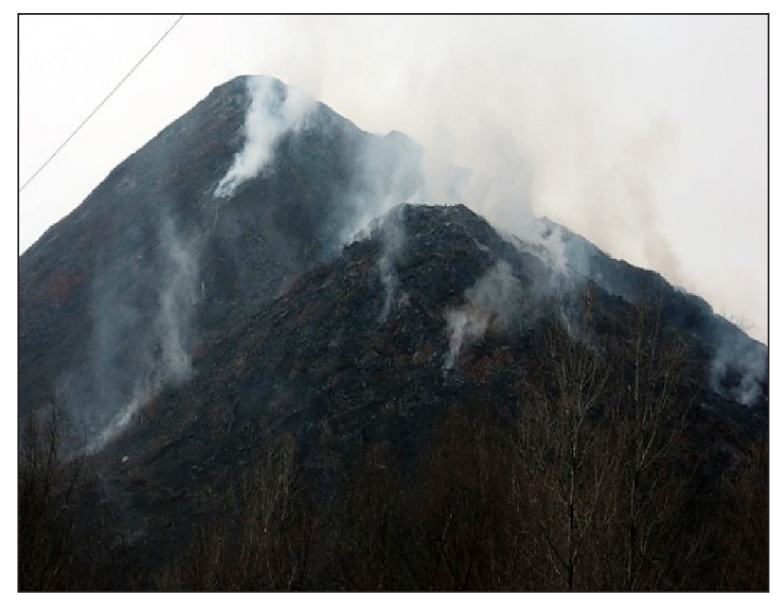

Fig. 2. Smouldering spoil banks 
of the maximum allowable concentration of the main types of pollutants was recorded in the zone of burning spoil banks: hydrogen sulfide 1.5-5 times, dust $-1.5-4.3$ times, sulfur dioxide - 1.3-2.4 times, nitrogen dioxide $-1.3-2$ times, carbon monoxide $-1.2-1.5$ times.

The chemical elements contained in the emissions (zinc, copper, lead, cadmium, nickel), have a negative influence on the central nervous system of the person, and the liver, change the formula of blood, cause cancer. All that increases the cost of medical care and social security for the people living in the mining regions (Pavlychenko et al., 2014). As a result of the influence of the mining workings of the existing and closed down mines, the groundwater levels rise, the aggregations of the earth's surface are intensified and the flood processes are observed (Yakovlyev et al., 2011).

In general, the negative impact of spoil banks on the environment is as follows:

- change in the hydrogeological regime of the adjoining territories;

- change in the terrain surface;

- dust and gas pollution of the atmosphere;

- chemical and radiological toxicity of soils and waters;

- disturbance of the equilibrium of the geological, physical and mechanical condition of the rock massif;

- blowing and washing of harmful components, contamination of soils and reduction of their fertility;

- the combined effect of the spoil banks that burn at the joining areas of the combustion products spread.

The most common methods of clearing the hydrosphere from the wastewater pollution of spoil banks are reagent (Gomelya et al., 2014), adsorption (Malovanyy et al. 2013), electrodialysis (Shmandiy et al., 2017), vibration and cavitation ones (Starchevskyy et al. 2017).

In order to reduce the harmful effects of the spoil banks on the environment, the main areas of their exploitation can be reclamation (which is inappropriate, since there are large areas of fertile land under the dumps) or recycling and utilizing them as man-made raw materials.

It is more efficient to use combustion metamorphic rocks after processing them with organic binders (Dvorkin and Dvorkin 2007). This work presents the technology of its application in the base-course of road pavement by reinforcing them with polypropylene binders (TPB).

\section{MATERIALS AND METHODS}

The experimental research involved the following objects:

1. Combustion metamorphic rocks of the extinct spoil bank of the mine № 6 "Chervona Zirka" (the city of Donetsk).

2. Modified environment - coal tar with conditional viscosity in $\mathrm{C}$ (in seconds), $\mathrm{C}_{30}^{10}=$ 50 secs, $C_{30}^{10}=150$ secs, $C_{30}^{10}=250$ secs, where: 10 - the diameter of the drain hole, $\mathrm{mm}$;

30 -the temperature of the material during the test at ${ }^{\circ} \mathrm{C}$, which consists of medium-temperature coal tar and anthracene oil.

Coal tars are produced in the course of destructive processing of bituminous coal. They are of the D-1-D-6 grades, depending on their conditional viscosity.

3. A polymer is a polystyrene production waste, polystyrene dust is a chemical industry waste (Open Joint Stock Company «Concern Styrol», Gorlivka, Donetsk region), which is formed during the settling of sewage in the styrene polymerization shops and is a fine white powder with a molecular weight of $9 \cdot 10^{4}$ of the carbon-bearing units and the particle size less than $6.3 \cdot 10^{-5} \mathrm{~m}$. The actual density of these wastes is $1050-1100 \mathrm{~kg} / \mathrm{m}^{3}$, and the bulk density is $650-720 \mathrm{~kg} / \mathrm{m}^{3}$.

The rational granulometric composition of combustion metamorphic rocks was determined using laboratory sieves, and the strength at compression of CMRM in a cylinder and the compressive strength (CMRM-TPB) of concrete on the hydraulic press.

TPB was prepared in a laboratory mixer (Fig. 3) by combining carbonaceous tar with a polymer (from $0 \%$ to $10 \%$ ) at the temperature of $105-110^{\circ} \mathrm{C}$ (Povzun et al. 2015) for 5-145 minutes (according to the matrix of the experiment planning), and their conditional viscosity (in seconds) was determined on a standard viscometer (Fig.4).

The temperature of softening was determined on the "Ring and ball" device (Fig. 5), and the tensile strength was determined on the ductilometer (Fig. 6). The elasticity of organic binders was calculated according to the formula (Goxman 2011):

$$
E=\frac{\ell-\ell_{1}}{\ell} \cdot 100 \%
$$




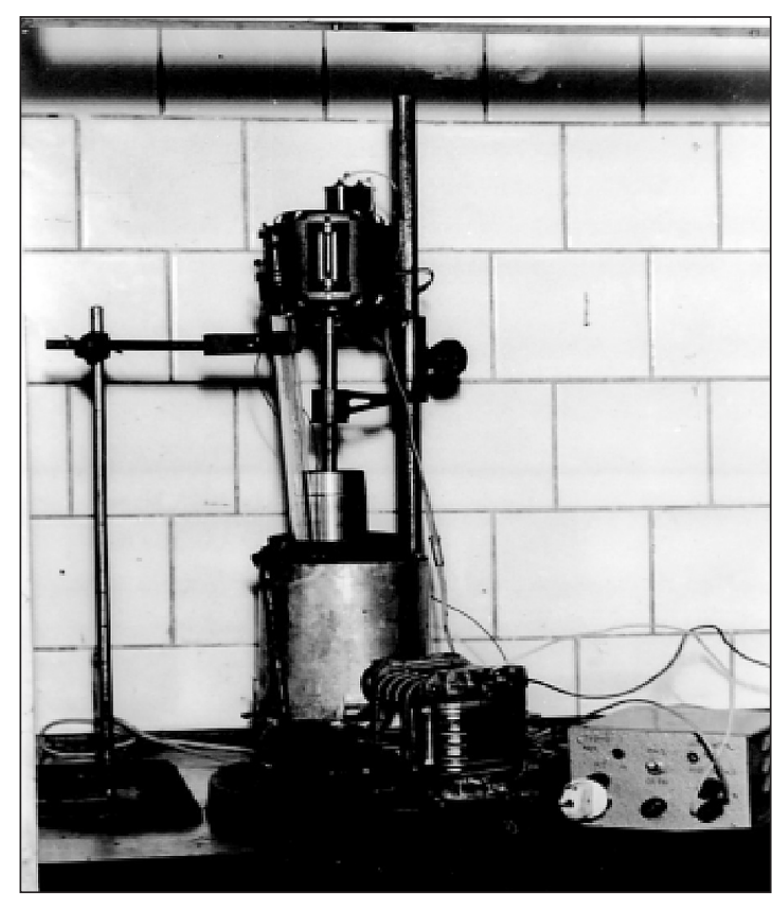

Fig. 3. Laboratory mixer

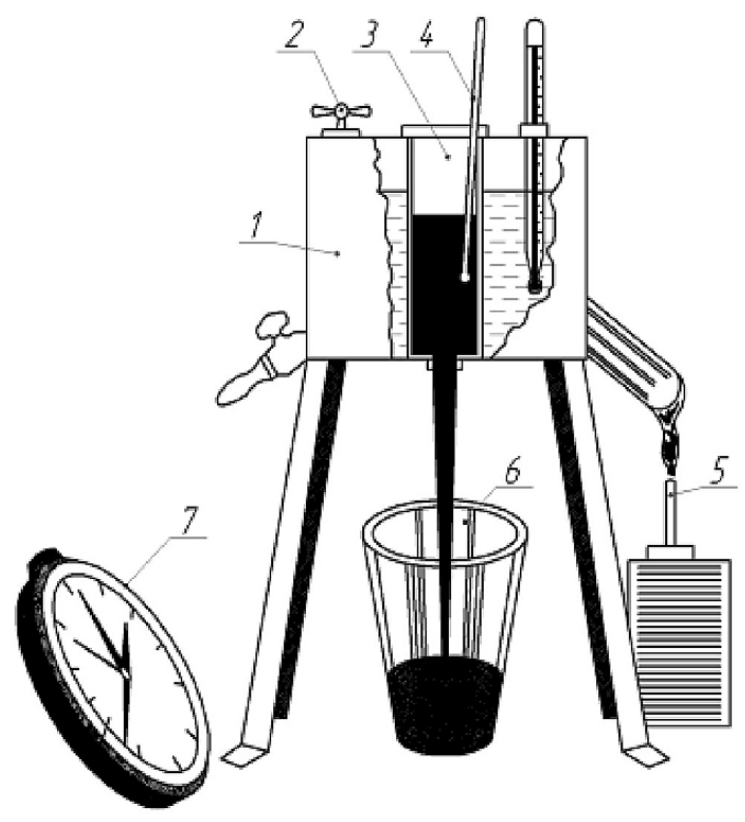

Fig. 4. Design of a standard viscometer

where $\ell$ is the length of the thread of the binder when it tears, $\mathrm{cm}$;

$\ell_{1}$ is the length of the binder after the renewal (after 5 minutes after tearing), $\mathrm{cm}$.

\section{RESULTS AND DISCUSSION}

The criteria for determining the rational granulometric composition of CMRM C1, C2 and C3

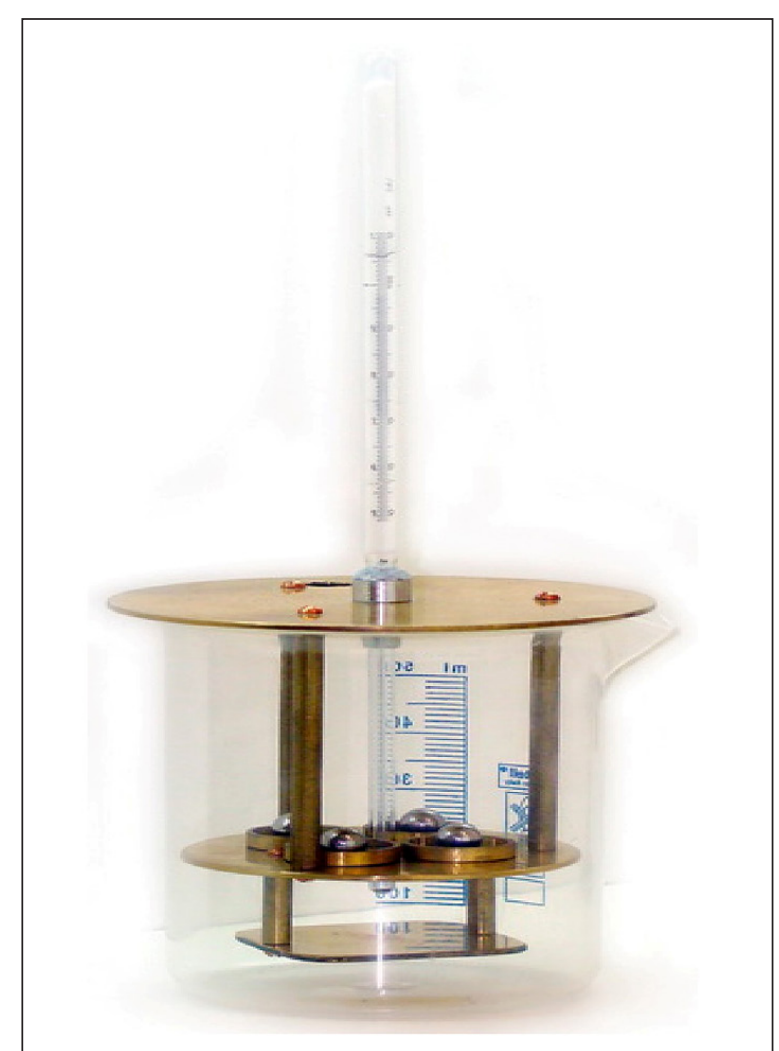

Fig. 5. The "Ring and ball" device

(Table 1) involved their bulk density and compressive strength in a metal when pressed in metallic cylinder on a hydraulic press.

The base course of the road pavement made of combustion metamorphic rocks of spoil banks is constructed in the following way (Fig. 7):

1. A bedding crushed stone layer of finegrained CMRM C1 (the largest stone size is $10 \mathrm{~mm}$ ) of the rational granulometric composition is placed on the planned surface of the earth roadbed (position 1).

1 - a compressed bedding crushed stone layer of rational granulometric composition (Table 1, mixture $\mathrm{C} 1$ );

2 - a compressed layer over the tracks which is made of crushed stone of rational granulometric composition (Table 1, mixture $\mathrm{C} 2$ );

3 - a layer made of a mixture of rational granulometric composition (Table 1, mixture C3);

6 - a car dump truck for laying crushed mixture C2 (Table 1) over the tracks;

7 - a compactor for compaction of crushed stone; 8 - a car dump truck for laying the crushed stone mixture C3 (Table 1) between the tracks.

The laid mixture is spread with an autogenerator. First, it is compacted by means of a light or medium roller compactor with metal rollers, and 


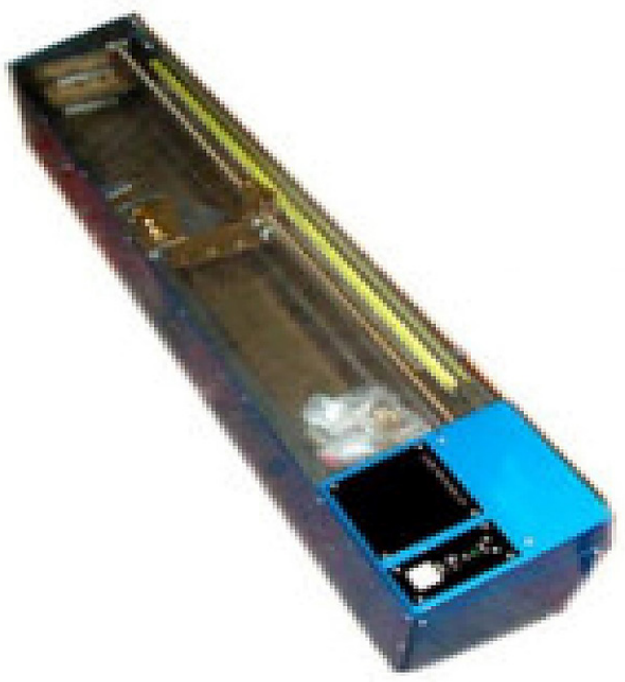

Fig. 6. Ductilometer

then with a heavy roller compactor. The number of passes is set by trial. Saggings are flattened. Rolling is finished when there is no deformation after a pass of the roller. In the dry season, it is advisable to water the layer $-4-51 / \mathrm{m}^{2}$.

In the layers of the crushed stone of the base course, the force transfer between the stones is done in a finite number of contact zones, which have a limited area. In this case, the work of the structural layer in the elastic stage is possible only at the expense of the stones which guarantee the stability of their shape and mutual arrangement under the influence of external loading.

In the crushed stone, which is easily compacted (namely, it is crushed stone from combustion metamorphic rock), the contact area of the stones, which are formed at the time of compacting, is larger, so the elastic convergence of a couple of stones is lesser than that of crushed stone, which is compacted with difficulty. At the time of rolling, the crushed stone becomes smaller and fills the intergranular cavity, with the simultaneously denser and stronger rubbing of the crushed stone granules with each other. Due to the high content of the flat crushed stone granules, the granules of the combustion metamorphic rock are also crushed while being rolled, which positively affects the improvement in the shape of the crushed stone granules needed for them to stick tightly. The stresses that occur in individual crushed stone granules appear to be much lesser than in the case of sticking through point contacts.

2. On the axes of the future tracks and at the distance of about $1.6 \mathrm{~m}$ between them, a dump truck (position 7) pours the windrow of coarse crushed stone mixture $\mathrm{C} 2$ of a rational granulometric composition with the largest grain size of crushed stone amounting to $160 \mathrm{~mm}$ (position 2), which is first rolled with light roller compactors, and then with heavy ones (item 6). The width of

Table 1. Rational granulometric compositions of the crushed combustion metamorphic rocks

\begin{tabular}{|c|c|c|c|c|c|c|c|c|c|c|c|c|}
\hline \multirow[b]{2}{*}{$\begin{array}{c}\text { № } \\
\text { mixture }\end{array}$} & \multirow{2}{*}{$\begin{array}{c}\text { The } \\
\text { largest } \\
\text { size of } \\
\text { stone, } \\
\mathrm{mm}\end{array}$} & \multicolumn{11}{|c|}{ What is left (\%) on sieves in size, $\mathrm{mm}$} \\
\hline & & 160 & 80 & 40 & 20 & 10 & 5 & 2,5 & 0,63 & 0,16 & 0,071 & $<0,071$ \\
\hline $\mathrm{C} 1$ & 10 & - & - & - & - & $0-10$ & $30-55$ & $40-62$ & $55-75$ & $65-82$ & $73-88$ & 100 \\
\hline $\mathrm{C} 2$ & 160 & $0-10$ & $30-55$ & $40-62$ & $50-70$ & $55-75$ & $60-80$ & $65-82$ & $70-88$ & $75-93$ & $80-95$ & 100 \\
\hline C3 & 80 & - & $0-10$ & $30-55$ & $40-62$ & $50-70$ & $55-75$ & $60-80$ & $68-85$ & $72-90$ & $80-95$ & 100 \\
\hline
\end{tabular}

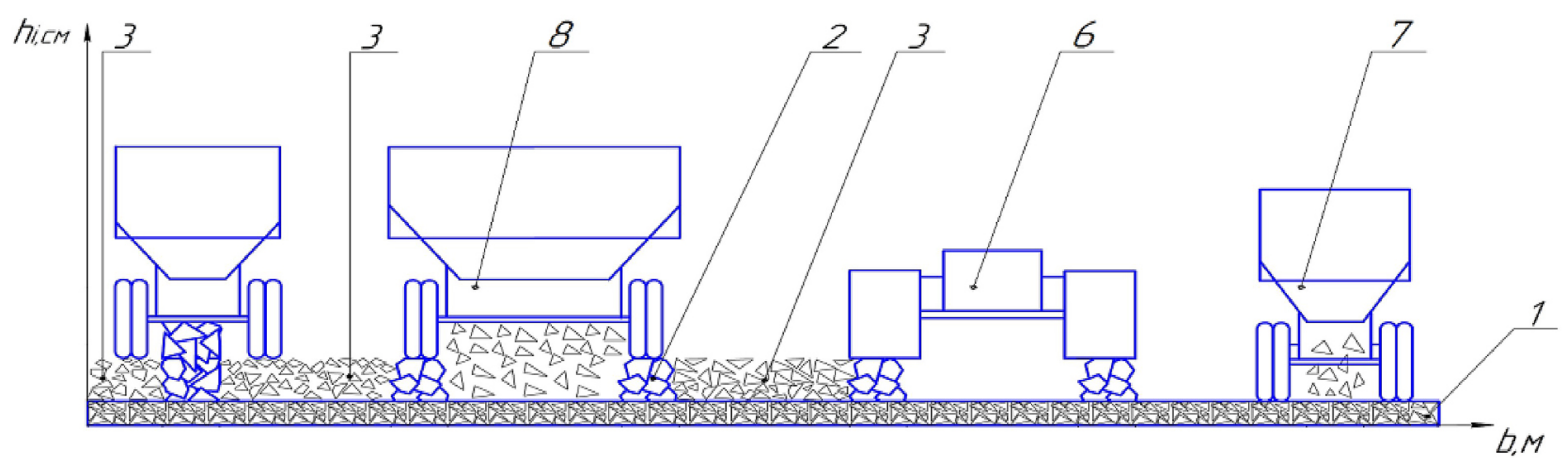

Fig. 7. Scheme of sequential laying and compacting the crushed stone mixtures made from combustion metamorphic rocks of rational granulometric compositions. 
the roller is about $0.5 \mathrm{~m}$, the height is about $16-18$ $\mathrm{cm}$. At the distance of $2 \mathrm{~m}$ from the axis of the first windrow, the second windrow is poured using the mixture of $\mathrm{C} 2$, etc., which is also smoothed and compacted. The windrows are formed with the mixture of $\mathrm{C} 2$ within the entire width of the road.

3. A mixture of combustion metamorphic rocks C3 (item 3) of a rational granulometric composition with the largest granule size of crushed stone is laid at the height of $80 \mathrm{~mm}$, which is of the same height as the previous windrows made from the mixture of $\mathrm{C} 2$, between the laid and compacted windrows along the tracks (of the crushed stone mixture $\mathrm{C} 2$ ) by a dump tuck (position 8). The mixture $\mathrm{C} 3$ is also smoothed and compacted.

5. The layers of the crushed combustion metamorphic rock of rational granulometric compositions (mixture of $\mathrm{C} 2$ and $\mathrm{C} 3$ ) are laid, smoothed and compacted for the second time.

6. The fine-grained CMRM C1, mixed with the carbonaceous binder, a modified polystyrene waste (item 4) with a thickness of $3 \mathrm{~cm}$ (Fig. 8) is laid on the entire lower part of the road base course made of the $\mathrm{C} 2$ and $\mathrm{C} 3$ mixtures.

2, 3 - the same as in Fig. 8

4 - the layers and the mixture of low-strength crushed stone CMRM (it is mixture $\mathrm{C} 1$ for its granulometry), which is mixed with TPB;

5 - a constructive layer of large, solid debris of the combustion metamorphic rock in the size of $250-400 \mathrm{~mm}$.

7. A constructive layer made of large, solid debris of the combustion metamorphic rock in the size of $250-400 \mathrm{~mm}$ (position 5) is laid in the upper part of the base course of the road pavement, the void between them and above them is filled with (CMRM-TPB) C1 (position 4).

8. The road base course is rolled out.

In order to determine the optimal concentration of polystyrene dust in coal tar of different viscosities and the optimal time of preparation of TPB binders, a composite asymmetric plan was adopted on three integer levels $(-1$; $0 ;+1)$. The optimal compositions of the system "tar - polystyrene dust" were defined as optimal areas of admissible values of the factors $X_{1}$, $X_{2}, X_{3}$ (Table 2).

These optimal areas are limited by the surface of the response function level for each of the optimization parameters (Table 3 ).

The experiment planning matrix and the obtained optimization parameters are given in Table 4.

The $D$-optimality was taken as the criterion for the optimality of the plan, which is related to minimizing the volume of the scattering of the estimates of the parameters of the regression equations. For the created plan of the experiment, using the least squares method, the coefficients of the regression equations were calculated by means of the expression:

$$
b_{i}=\left(X^{*} \cdot X\right)^{-1} \cdot X^{*} \cdot Y
$$

where $b_{i}$ is the coefficient of the regression equation;

$X$ - matrix of the experiment plan;

$X^{*}-$ transposed matrix of the experiment plan;

$\left(X^{*} \cdot X\right)^{-1}$ is the matrix, inverse to the product of the matrix of the experiment plan on its transposed matrix;

$Y$ - vector column of the results of the experiment.

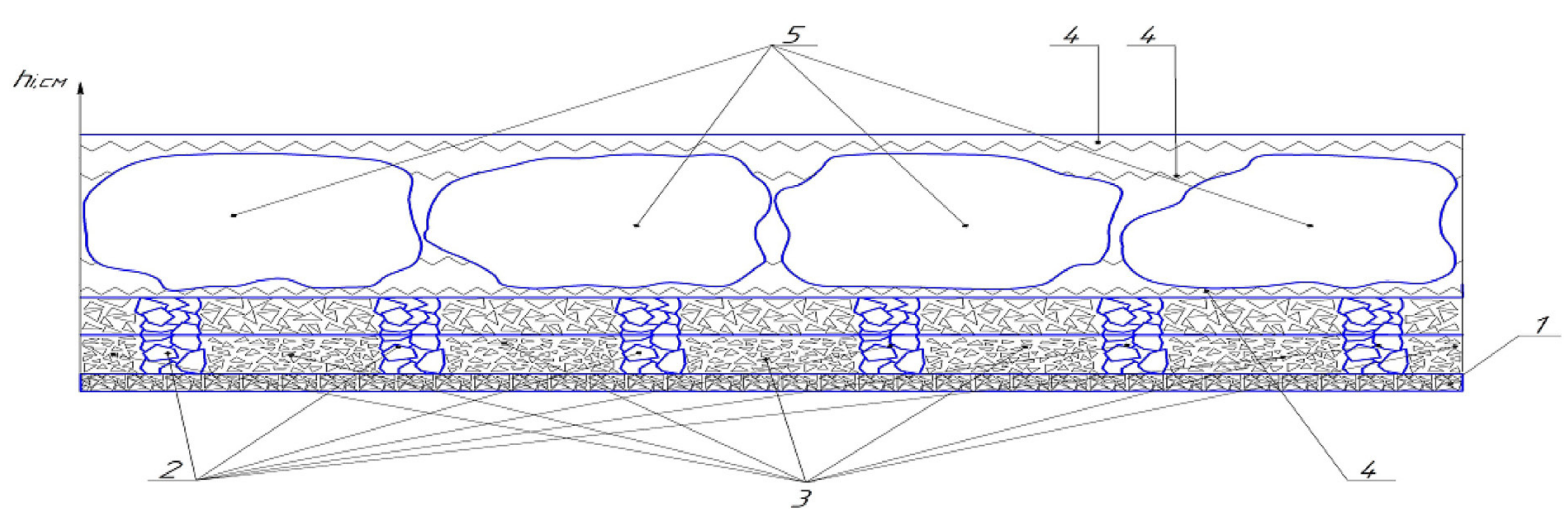

Fig. 8. The base course of the road made of the combustion metamorphic rocks of spoil banks. 
Table 2. Values of variation factors

\begin{tabular}{|c|c|c|c|c|c|}
\hline \multirow{2}{*}{\multicolumn{3}{|c|}{ System }} & \multicolumn{3}{|c|}{ Physical content of the variation factor } \\
\hline & & & \multirow{2}{*}{$\begin{array}{c}\text { Conditional } \\
\text { viscosity of tar in } \\
\text { C, sec } \\
X_{1}\end{array}$} & \multirow{2}{*}{$\begin{array}{c}\begin{array}{c}\text { Bulk density of } \\
\text { polystyrene dust, } \%\end{array} \\
X_{2}\end{array}$} & \multirow{2}{*}{$\begin{array}{l}\text { Preparation time of TPB, min. } \\
\qquad X_{3}\end{array}$} \\
\hline & & & & & \\
\hline \multirow[b]{2}{*}{$\begin{array}{c}\text { Tar - } \\
\text { Polystyrene }\end{array}$} & \multicolumn{2}{|c|}{ Variation interval } & 100 & 5 & 70 \\
\hline & $\begin{array}{l}\text { Factor variation } \\
\text { levels }\end{array}$ & $\begin{array}{c}-1 \\
0 \\
+1\end{array}$ & $\begin{array}{c}50 \\
150 \\
250\end{array}$ & $\begin{array}{c}0 \\
5 \\
10\end{array}$ & $\begin{array}{c}5 \\
75 \\
145\end{array}$ \\
\hline
\end{tabular}

Table 3. Parameters for optimization of the system «tar - polystyrene dust»

\begin{tabular}{|c|c|l|c|c|}
\hline № & $\begin{array}{c}\text { Optimization } \\
\text { parameter code }\end{array}$ & \multicolumn{1}{|c|}{ Physical content of the optimization parameter } & $\begin{array}{c}\text { Units of } \\
\text { measurement }\end{array}$ & $\begin{array}{c}\text { Limit values of the } \\
\text { response function }\end{array}$ \\
\hline 1 & $Y_{1}$ & The softening temperature of the binder & ${ }^{\circ} \mathrm{C}$ & Not less than30 \\
\hline 2 & $Y_{2}$ & Elasticity of the binder at $0^{\circ} \mathrm{C}$ & $\%$ & Not less than15 \\
\hline 3 & $Y_{3}$ & Extension of the binder at 0oC & $\mathrm{m}$ & Not less than 0,85 \\
\hline 4 & $Y_{4}$ & Strength limit (CMRM_TPB) for compression at $20^{\circ} \mathrm{C}$ & $\mathrm{MPa}$ & Not less than2,0 \\
\hline 5 & $Y_{5}$ & Long-term water resistance coefficient (BBM-TPK) & - & Not less than0,7 \\
\hline
\end{tabular}

Table 4. The matrix of the experiment plan and the obtained values of optimization parameters

\begin{tabular}{|c|c|c|c|c|c|c|c|c|c|c|c|c|c|}
\hline No. & $X_{1}$ & $X_{2}$ & $X_{3}$ & $Y_{11}$ & $Y_{12}$ & $Y_{21}$ & $Y_{22}$ & $Y_{31}$ & $Y_{32}$ & $Y_{41}$ & $Y_{42}$ & $Y_{51}$ & $Y_{52}$ \\
\hline 1 & -1 & -1 & -1 & 10 & 12 & 0 & 0 & 0,98 & 1,00 & 1,5 & 1,7 & 0,3 & 0,5 \\
\hline 2 & 0 & -1 & 0 & 18 & 22 & 0 & 0 & 1,00 & 0,96 & 2,5 & 2,1 & 0,7 & 0,5 \\
\hline 3 & 1 & -1 & 1 & 22 & 24 & 0 & 0 & 0,01 & 0,03 & 2,2 & 2,6 & 0,8 & 0,6 \\
\hline 4 & -1 & 0 & 0 & 21 & 25 & 26 & 24 & 1,00 & 0,96 & 2,5 & 2,1 & 1,0 & 0,6 \\
\hline 5 & 0 & 0 & 1 & 29 & 25 & 2 & 4 & 0,03 & 0,01 & 2,1 & 2,7 & 0,7 & 0,9 \\
\hline 6 & 1 & 0 & -1 & 31 & 35 & 13 & 11 & 1,00 & 0,97 & 1,4 & 1,8 & 0,6 & 0,4 \\
\hline 7 & -1 & 1 & 1 & 29 & 25 & 4 & 2 & 0,01 & 0,03 & 2,6 & 2,2 & 0,7 & 0,9 \\
\hline 8 & 0 & 1 & -1 & 33 & 29 & 10 & 14 & 0,06 & 0,04 & 1,8 & 1,2 & 0,7 & 0,5 \\
\hline 9 & 1 & 1 & 0 & 33 & 37 & 9 & 7 & 0,97 & 1,00 & 1,8 & 1,4 & 0,5 & 0,9 \\
\hline 10 & -1 & -1 & 1 & 12 & 10 & 0 & 0 & 0,04 & 0,02 & 2,1 & 2,7 & 0,6 & 0,4 \\
\hline 11 & 1 & -1 & -1 & 20 & 24 & 0 & 0 & 0,96 & 1,00 & 1,2 & 1,8 & 0,7 & 0,5 \\
\hline 12 & -1 & 1 & -1 & 26 & 28 & 7 & 9 & 1,00 & 0,97 & 1,8 & 1,4 & 0,4 & 0,6 \\
\hline 13 & 1 & 1 & 1 & 37 & 33 & 4 & 2 & 0,03 & 0,01 & 2,7 & 2,1 & 0,9 & 0,7 \\
\hline
\end{tabular}

The processing of the experiment results and the determination of the regression equations coefficients, taking into account their significance, enabled obtaining polynomial models.

The statistical analysis of the obtained results includes the verification of two statistical hypotheses:

- about the significance of the obtained coefficients of the model;

- about the adequacy of representing the results of the experiment with the obtained regression equation.

The coefficients of the regression equation are subjected to a polynomial form as follows:

$$
\begin{aligned}
Y= & b_{0}+b_{1} X_{1}+b_{2} X_{2}+b_{3} X_{3}+b_{12} X_{1} X_{2}+b_{13} X_{1} X_{3}+ \\
& +b_{23} X_{2} X_{3}+b_{11} X_{1}^{2}+b_{22} X_{2}^{2}+b_{33} X_{3}^{2}
\end{aligned}
$$

For each of the optimization parameters, the regression coefficients, which are placed into equation (2), were calculated in accordance with the formula (1). The regression equations for each optimization parameter are as follows:

$$
\begin{aligned}
-Y_{1}= & 28.97+4.90 \cdot X_{1}+6.79 \cdot X_{2}+0.003 \cdot X_{3}- \\
& -1.03 \cdot X_{1} \cdot X_{2}+0.06 \cdot X_{1} \cdot X_{3}-0.014 \cdot X_{2} \cdot X_{3}- \\
& -0.70 \cdot X_{1}^{2}-3.24 \cdot X_{2}^{2}-1.22 \cdot X_{3}^{2} \\
-Y_{2}= & 14.9-1.09 \cdot X_{1}+3.39 \cdot X_{2}-2, .28 \cdot X_{3}- \\
& -0.24 \cdot X_{1} \cdot X_{2}+0.054 \cdot X_{1} \cdot X_{3}-2.07 \cdot X_{2} \cdot X_{3}+ \\
& +3.91 \cdot X_{1}{ }^{2}-9.65 \cdot X_{2}^{2}-6.24 \cdot X_{3}^{2}
\end{aligned}
$$


Table 5. Statistical data of the results of the received experimental data processing

\begin{tabular}{|l|c|c|c|c|c|}
\hline \multicolumn{1}{|c|}{ Indexes } & $Y_{1}$ & $Y_{2}$ & $Y_{3}$ & $Y_{4}$ & $Y_{5}$ \\
\hline The sum of dispersions & 26 & 11 & 30 & 0,52 & 0,11 \\
\hline Average dispersion of the experiment $D_{\text {exp. }}$ & 5,333 & 0,846154 & 5,6667 & 0,1111 & 0,02333 \\
\hline The sum of dispersions of the model & 4,8087 & 107,47 & 2665,4 & 0,14103 & 0,02389 \\
\hline Dispersion of adequacy, $D_{\text {adeq. }}$ & 0,3699 & 8,2668 & 205,03 & 0,01084 & 0,00183 \\
\hline $\mathrm{F}_{\text {Fisher's }}=\mathrm{D}_{\text {exp. }} / \mathrm{D}_{\text {adeq. }}$ & 14,418 & 0,1023 & 0,0276 & 10,2420 & 12,6938 \\
\hline
\end{tabular}

Table 6. Areas of permissible values of mass concentrations of polystyrene dust $\left(X_{2}\right)$ and preparation time of $\operatorname{TPB}\left(X_{3}\right)$

\begin{tabular}{|l|c|c|}
\hline \multirow{2}{*}{ Optimization parameter } & \multicolumn{2}{c|}{ Variation factors } \\
\cline { 2 - 3 } & $\begin{array}{c}\text { The mass concentration of } \\
\text { polystyrene dust, } \%,\left(X_{2}\right)\end{array}$ & $\begin{array}{c}\text { Preparation time of TPB, min, } \\
\left(X_{3}\right)\end{array}$ \\
\hline Temperature of softening of $\mathrm{TPB}^{\circ} \mathrm{C},\left(Y_{1}\right)$ & $6 \leq X_{2} \leq 10$ & $5 \leq X_{3} \leq 145$ \\
\hline Elasticity of TPB at $0{ }^{\circ} \mathrm{C}, \%,\left(Y_{2}\right)$ & $5 \leq X_{2} \leq 7$ & $47 \leq X_{3} \leq 75$ \\
\hline Stretch of TPB at 0oC, $\mathrm{m}\left(Y_{3}\right)$ & $0 \leq X_{2} \leq 7$ & $33 \leq X_{3} \leq 75$ \\
\hline $\begin{array}{l}\text { Strength limit(CMRM }-\mathrm{TPB}) \text { for compression at 20oC, MPa } \\
\left(Y_{4}\right)\end{array}$ & $0 \leq X_{2} \leq 10$ & $47 \leq X_{3} \leq 75$ \\
\hline Long-term water resistance coefficient $(\mathrm{CMRM}-\mathrm{TPB}),\left(Y_{5}\right)$ & $1 \leq X_{2} \leq 10$ & $47 \leq X_{3} \leq 145$ \\
\hline
\end{tabular}

$$
\begin{aligned}
-Y_{3}= & 0.879-0.010 \cdot X_{1}-0.098 \cdot X_{2}-0.384 \cdot X_{3}- \\
& -0.043 \cdot X_{1} \cdot X_{2}+0.046 \cdot X_{1} \cdot X_{3}+0.089 \cdot X_{2} \cdot X_{3}+ \\
& +0.311 \cdot X_{1}{ }^{2}-0.135 \cdot X_{2}^{2}-0.614 \cdot X_{3}^{2} ; \\
-Y_{4}= & 2.222-0.083 \cdot X_{1}-0.075 \cdot X_{2}+0.426 \cdot X_{3}- \\
& -0.062 \cdot X_{1} \cdot X_{2}+0.050 \cdot X_{1} \cdot X_{3}+0.033 \cdot X_{2} \cdot X_{3}- \\
& -0.072 \cdot X_{1}{ }^{2}-0.130 \cdot X_{2}{ }^{2}-0.086 \cdot X_{3}^{2} ; \\
-Y_{5}= & 0.789-0.025 \cdot X_{1}-0.058 \cdot X_{2}+0.106 \cdot X_{3}- \\
& -0.057 \cdot X_{1} \cdot X_{2}+0.014 \cdot X_{1} \cdot X_{3}+0.048 \cdot X_{2} \cdot X_{3}- \\
& -0.036 \cdot X_{1}^{2}-0.069 \cdot X_{2}{ }^{2}-0.091 \cdot X_{3}^{2} \cdot
\end{aligned}
$$

The obtained regression equations are adequate and meet the Fisher's criterion; the results of their processing are given in Table 5 .

Using the interval method, it was determined that the optimal system "coal tar - polystyrene dust" will be at mass concentrations of $6-7 \%$ polystyrene dust $\left(X_{2}\right)$ and $47-75$ minutes of preparing TPB $\left(X_{3}\right)$ (Table 6).

\section{CONCLUSION}

The environmentally friendly technology of laying the base courses of highways, which is made of coal industry waste - burnt rocks of spoil banks, was offered. The rational granulometric composition of BBM with different grain size of gravel was determined. The expediency of reinforcing the base course made from the debris with coal tar, which is modified waste from the chemical industry - wastes from the production of polystyrene (polystyrene dust) was shown.

The experimental laboratory tests of TPB and (CMRM - TPB) were carried out. The mathematical modelling of the organic binder of the coke production, which is modified by polystyrene dust, was carried out. On the basis of the chosen factors of variation and optimization parameters, the optimal composition of TPB was determined: the optimum mass concentration of polystyrene dust in coal tar is $6-7 \%$, and the term of its preparation is $47-75$ minutes. Utilization of coal and chemical industry waste in road construction will improve the ecological situation in the coal mining region:

- to re-cultivate valuable areas of land under the waste landfills;

- to improve the sanitary and hygienic conditions for the use of these wastes;

- to create the conditions for non-waste production of coal mines and chemical plants in the future.

\section{REFERENCES}

1. Bogach K.S. 2013. Vyznachennya zasad ekologoekonomichnoyi polityky' povodzhennya $\mathrm{z}$ vidvalamy girskoyi porody vugilnyx shaxt. Visnyk Sxidnoyevropejskogo universytetu ekonomiky i menedzhmentu. 2 (15), 101-110. (in Ukrainian).

2. Gochman L.M. 2011. Vliyanyje elastychnosti organicheskych vyazhushhych na nakoplenie 
ostatochnyx deformacij v binarnyx smesyax. Nauka i texnika v dorozhnoj otrasli. 1, 31-33. (in Russian).

3. Gomelya M. et al. 2014. Application of aluminium coagulants for the removal of sulphate from mine water. Chemistry and Chemical Technology. 8(2), 197-203.

4. Gorova, A. et al. 2013. The investigation of coal mines influence on ecological state of surface water bodies. Annual Scientific-Technical Colletion Mining of Mineral Deposits. Leiden, The Netherlands, 303-305.

5. Dvorkin L.Y, Dvorkin. O.L. 2007. Stroitelnye materialy iz otchodov promyshlennosti. Rostov-na Donu: Izd-vo «Feniks». (in Russian).

6. Kasymov A.M. et al. 2010. Terrykonы otvalnых porod Donbassa - syrevoj potencyal Ukrainy. ekologiya y` promyshlennosti. 1, 68-72. (in Russian).

7. Kuzyk I.M., Artamonov V.M. 2013. Vyznachennya ekologichnyx ryzykiv pry funkcionuvanni porodnogo vidvalu ta obgruntuvannya napryamkiv shhodo yix podolannya (metodologichnyj aspekt). Geodeziya, kartografiya i aerofotoznimannya. Visn NU «Lvivska politexnika». 78, 234-240. (in Ukrainian).

8. Malovanyy M. et al. 2013. Water sorption purification from ammonium pollution. Chemistry and chemical technology. 7(3), 355-358.

9. Maznyczka O.V. et al. 2011. Chynnyky fitotoksychnogo vplyvu gruntiv vidvaliv girskyx porid. Novi texnologiyi. 1, 127-130. (in Ukrainian).

10. Pavlychenko A.V. et al. 2014. Development of electronic environmental passport of coal mine wasterock piles. Scientific Bulletin of National Mining University. 3, 105-110.

11. Pivnyak G.G. et al. 2011. Potencial zakrytoj shachty
- osnova reshenija problemy Post-mining. Zbirnyk prac «Forum girnykiv - 2011». 1. Dnipropetrovsk: Vyd-vo NGU. (in Russian).

12. PolulyaxA.D. et al. 2012. Texnologo-ekologicheskyj inzhyniring pry obogashhenii poleznych iskopaemych. Dnipropetrovsk: Vyd-vo NGU. (in Russian).

13. Povzun O.I. et al. 2015. Ukripleni kamyanovugilnym vyazhuchym gorili porody shaxtnych terykoniv v osnovax dorozhnix odyagiv. Visti Doneczkogo girnychogo instytutu. 1(36)-2(37), 142-150. (in Ukrainian).

14. Shago Ye. P. et al. 2011. Koncepciya vdoskonalennya sfery povodzhennya $z$ vidxodamy $\mathrm{v}$ Ukrayini na innovacijnyx zasadax. Visn. Vinnyczkogo politex. in-tu. 6, 17-19. (in Ukraine).

15. Shmandiy V. et al. 2017. Methods of salt content stabilization in circulating water supply systems. Chem. Chem. Technol. 11, 242-246.

16. Starchevskyy V. et al. 2017. The effectiveness of food industry wastewater treatment by means of different kinds of cavitation generators. Chem. Chem. Technol. 11, 358-364.

17. Syvyj M. Ya. 2012. Do problemy utylizaciyi girnychopromyslovyx vidxodiv u Vinnyczkij oblasti. Ekologichna bezpeka ta zbalansovane resursokorystuvannya. 2(6), 84-88. (in Ukrainian).

18. Vojcexovskaya E. Yu. et al. 2012. Ocenka porodnych otvalov ugolnych predpriyatij Doneczkogo bassejna kak kompleksnoj nagruzki na okruzhayushhuyu pryrodnuyu sredu i puti ee snizhenija. Problemy ekspluataciyi obladnannya shaxtnych stacionarnych ustanovok. 106-107, 276-282. (in Russian).

19. Yakovlyev Ye.O. et al. 2011. Ekologo-resursni ta ekologo-texnogenni zagrozy nacionalnij bezpeci Ukrayiny. Kyiv: NISD. (in Ukrainian). 